\title{
Support Competitiveness for Egyptian Carpet Facility by Applying the Con- cept of Cleaner Production
}

\author{
Shaymaa Ahmed Mohamed Ahmed \\ Lecturer at Spinning, Weaving \& Knitting Department Faculty of Applied Arts, Beni Swief University, Cairo, Egypt.
}

\begin{tabular}{l|l|l|} 
Submit Date: 2021-08-09 02:41:08 & Revise Date:2021-10-23 21:44:04 & Accept Date: 2021-11-03 07:48:57
\end{tabular}

DOI: 10.21608/jdsaa.2021.88983.1118

KEYWORDS:

cleaner production, competitiveness, environmental management systems, business performance, work environment.

\begin{abstract}
:
Gas pollution and emissions are a real threat to our planet. The world has begun to realize the criticalness of pollution after the Rio de Janeiro conference in 1992, which summarized the risks of industrial progress from gases and fumes rising from factories, means of transportation, fire, solid waste, chemical and radiation
\end{abstract}

materials. The conference was a spark and an alarm to the whole world. It also helped the ISO to issue The ISO Standard Specifications 14000

$-1996$.

By the end of the early eighties of last century, the concept of cleaner production Started to be frequently used as an entrance to reviewing and managing operations and performance through the business cycle, in addition to focusing on reducing waste and pollution from the source, the cleaner production became the most important method to incorporate the environmental dimension in industrial and productive processes, This proposed framework acquires great importance when Egypt signed the Kyoto Agreement, which obliges countries to rationalize and reduce industrial emissions as well as restrictions related to the export process and determine the level of quality of exported products.

So the researcher thought that applying the proposed framework for cleaner production within the Egyptian carpet facility aims to support the competitiveness of these facilities, while studying the conceptual framework for the concept of cleaner production. In addition to finding simplified steps to apply the concept within any textile facility, Where the status of the facility was examined before the implementation of the concept of cleaner production and the problems it suffers from (Low labor awareness, high quantities of the second degree, wasteful consumption of raw materials and energy sources, and the use of non - environmentally friendly energy sources, the presence of large quantities of solid and liquid waste and emissions of dust and toxic gases), where these problems and their causes were measured, and a team was formed to implement the concept of cleaner production and assist the researcher, then meetings were held to study and determine solutions and time frame for implementing these solutions, then the application and measurement of these problems was carried out after the appli- 
cation of the proposed solutions, where the clear improvement appeared in all problems, the improvement of work environment, the lower cost for products and higher competitiveness for the facility

Research Problem: A lot of Egyptian textile factories suffer from many problems as well as the facility under study such as low labor awareness, high quantities of the second degree, wasteful consumption of raw materials and energy sources, and the use of non - environmentally friendly energy sources, the presence of large quantities of solid and liquid waste and emissions of dust and toxic gases, decreased competitiveness so the researcher's thinking was in a concept that has the ability to treat these problems.

Research Significance: Establishing a framework for applying the concept of cleaner production, which helps to find a product and work environment that are ecofriendly, by achieving:

- The clients and workers' satisfaction about the work environment, preserving the environment and reducing environmental waste.

- Reducing the production cost by: rationalizing the use of resources, reducing negligible energy use, reducing waste, recycling and reducing transportation costs.

- Benefiting from several advantages in financing as a result of applying environmental policies, and thus protecting the environment.

- Increasing the marketing share of the facility locally and globally; as cleaner production helps customers achieve their environmental goals, which increases the facility's ability to environmental disclosure and spreading information about the environmental aspects of the facility's products. Consequently, this helps to increase the products demanding and contribute to opening new marketing outlets in different countries all over the world with different environmental considerations.

\section{Research Hypotheses:}

1. The application of the proposed framework serves for production without pollution or at least does not allow to exceed the limits of environmental safety, whether in accordance with

the laws or global environmental agreements and protocols.
2. The application of the proposed framework helps to improve productivity in its comprehensive concept. For instance, improving design quality, reducing the quantities of raw materials and energy consumed, reducing waste in resources, improving machinery performance, reducing emissions from the production process and improving overall operations.

3. The application of the proposed framework helps to increase the facility's marketing share and grow the satisfaction of workers and customers.

\section{Introduction:}

The industrial business environment witnessed in the last three decades a new stage characterized by the complexity and speed of the changes that surrounded its environment, which made the companies and industrial institutions face challenges that were reflected on their policies, and this resulted in adopting modern methods and approaches that achieve their requirements, pillars of continuity, competitiveness and preservation of the environment at the same time. Thus, the cleaner production is one of the most important entrances in this process (Ahmed, T \& Hamza, B, 2012) (Adel ,Z \& Wijdan, H. H,2012)

Cleaner production is the best way to achieve environmental progress and sustainable development that contribute to: preserving and ensuring the best use of the resources, reducing pollutants resulting from industrial processes, and achieving environmental well-being in both; the local and global levels. This can be achieved through multiple procedures. For instance, reducing global warming, increasing the efficiency of resource use, contributing to the modernization of industrial assets and achieving quality requirements, and finally, opening the way to export and increasing the demand for products.

The carpet industry is an integral part of the global industrial business environment, especially the Egyptian one. This industry has grown to become the largest and fastest Egyptian industry, as it is one of the most prominent Egyptian industries in the field of design, innovation and quality. (Ahmed, T \& Hamza, B, 2012).

\section{Theoretical Framework:}

The concept of competitiveness: It is the ability of a company to produce and deliver products or 
services to customers in a distinct way as competitors have not. Jean \& Lambin defined it as the set of characteristics that characterize a product that gives the organization some advantage over its competitors. The researcher believes that it can be defined as: the necessity of producing goods in a different and distinct way from the rest of competitors in order to achieve a competitive advantage whether in terms of price, product characteristics, for instance; the quality, the production of ecofriendly products and focusing on the customer's loyalty, to ensure the survival and continuity of the company in the light of environmental changes and increased competition intensity.

\section{Advantages of Competitiveness:}

Continuous and sustainable: that is, the necessity of continuous and sustainable improvement to keep up with developments and successive change, in order not to let the company lose its competitive position. (Bing, Z \& Shuchong, Y \& Jun , B, 2013).

Relativity: Means that competitiveness is relative when the company is compared to other competitors or compared to different time periods.

Renewed: according to the external environment data on the one hand and the capabilities and resources of the internal company on the other.

Proportionate: that the use of these competitive advantages is commensurate with goals and results that companies want to achieve in the short and long term.

Flexibility: it is possible to replace competitive advantages with others in a simple and flexible way according to the changes in the external environment in one hand and the improvement of the company's capabilities and resources on the other.

The concept of cleaner production:

Dr. Khaled Mustafa Qassem defined Cleaner Production as: a continuous and integrated strategy to avoid the negative effects of the production process and other related processes in health and environment. Eliana \& Others defined it: It is a tool that aims to improve the

environmental behavior in organizations, reduce production costs, increase efficiency and competitive ability, in order to improve health and security conditions workers, improve the company's image in the market, and increase the level of customer satisfaction. (Camila, D. W, \& Others, 2014).

As defined by the United Nations Environment Program (UNEP): it is the continuous application of an integrated strategy for environmental protection on operations, products and services in order to increase efficiency and reduce risks that would affect human health and the environment. The previous concepts have been applied until the recent global economic and environmental crises, now companies shift towards industrial systems that are more sustainable, which led to the expansion of the definition of cleaner production to include resource efficiency, that is the main element in the shift towards green industries in order to increase efficiency and reduce risks.

Accordingly, the United Nations Environment Program introduced a new definition of cleaner production called Resource Efficiency \& Cleaner Production (RECP), which focuses on:

- Production Efficiency: by maximizing the benefit from the use of products from natural resources, for instance, materials, energy and water in all stages of the product's life cycle. - Environmental Management: by reducing the negative effects of industrial production systems on nature and environment. (Bing, Z \& Shuchong, Y \& Jun , B, 2013).

- Human Resources: by reducing risks to people and society and supporting their development. The difference between cleaner production and sustainable development:

The concept of sustainable development appeared in the early nineties of the last century, it is the development that works to protect the environment resources, prevent pollution and uses available resources in a way that does not affect the needs of future generations by achieving a balance between the environment and development, through the incorporation of environmental considerations into economic activities. That's why they need efficient and

effective environmental management systems. Thus, it is necessary to have another dimension to achieve integration in productive companies, which is cleaner production. It is the dimension 
that is concerned with the transition to more efficient and cleaner technology that leads to the least amount of energy and resources used by society.

For making technology in the interest of economy, society and the environment at the same time the best solution is the sustainable development, therefore it was necessary to have:

- The technology should be applicable in the precompetition stage. (Carlos, H. R. M ,2013).

- That technological innovations should lead to economic, environmental and social benefits for society as a whole.

- Applying technological progress that reduces waste resulting from the use of traditional energy and focus on renewable energy instead of fuel.

Table (1) illustrates the difference between the concepts of Cleaner production and Environmental Management System

\begin{tabular}{|l|l|l|}
\hline Concept & $\begin{array}{l}\text { Cleaner Pro- } \\
\text { duction } \\
\text { CP }\end{array}$ & $\begin{array}{l}\text { Environmen- } \\
\text { tal Manage- } \\
\text { ment } \\
\text { System EMS }\end{array}$ \\
\hline Definition & $\begin{array}{l}\text { It is an ad- } \\
\text { vanced en- } \\
\text { vironmental } \\
\text { tool aimed at } \\
\text { preserving the } \\
\text { environment } \\
\text { and achieving } \\
\text { productive and } \\
\text { environmental } \\
\text { efficiency. }\end{array}$ & $\begin{array}{l}\text { It is the frame- } \\
\text { work estab- } \\
\text { lished by the } \\
\text { organization to } \\
\text { help improve } \\
\text { environmental } \\
\text { performance } \\
\text { by taking } \\
\text { environmental } \\
\text { considerations } \\
\text { into account } \\
\text { when making } \\
\text { decisions }\end{array}$ \\
\hline Range & $\begin{array}{l}\text { It includes } \\
\text { continuous } \\
\text { improvement } \\
\text { through prod- } \\
\text { uct design, } \\
\text { technology } \\
\text { techniques, } \\
\text { and operation- } \\
\text { al and behav- } \\
\text { ioral }\end{array}$ & $\begin{array}{l}\text { Plan activities, } \\
\text { responsibili- } \\
\text { ties, practices, } \\
\text { procedures and } \\
\text { resources need- } \\
\text { ed to develop, } \\
\text { implement } \\
\text { and achieve } \\
\text { environmental } \\
\text { policies. }\end{array}$ \\
\hline
\end{tabular}

\begin{tabular}{|l|l|l|}
\hline purpose & $\begin{array}{l}\text { Eliminating } \\
\text { the causes } \\
\text { of pollution } \\
\text { instead of } \\
\text { managing } \\
\text { the generat- } \\
\text { ed waste. }\end{array}$ & $\begin{array}{l}\text { The organization } \\
\text { is provided with an } \\
\text { assurance that its } \\
\text { environmental perfor- } \\
\text { mance meets its cur- } \\
\text { rent requirements and } \\
\text { extends and continues } \\
\text { to meet its policies } \\
\text { and legal }\end{array}$ \\
\hline $\begin{array}{l}\text { Main } \\
\text { field }\end{array}$ & $\begin{array}{l}\text { Human } \\
\text { practices, } \\
\text { energy } \\
\text { materials, } \\
\text { and } \\
\text { behavioral } \\
\text { changes. }\end{array}$ & $\begin{array}{l}\text { Manage information } \\
\text { from various } \\
\text { sources such as } \\
\text { legal requirements, } \\
\text { Operational } \\
\text { procedures and } \\
\text { training records.( } \\
\text { Bing, Z \& } \\
\text { Shuchong, Y \& Jun } \\
\text { B, 2013) } \\
\text { (Christopher, M. } \\
\text { W,2005). }\end{array}$ \\
\hline
\end{tabular}

\section{CP requirements:}

Dealing with initial requirements:

- relying on motivation as a first step to adopt cleaner production, which includes providing support for production inputs, providing soft loans for clean technologies, imposing penalties in the case of environmental non-compliance, building human awareness that of the importance of cleaner production and the ability to implement it, improving the environmental performance of the company, adopting approved environmental systems, and the use of ecofriendly materials in the production process.( KOSUKE ISHII,2001). - Approval of the techniques of reuse and recycling: Reuse means the repeated use of the product or its components that have become waste or used for purposes other than the main purpose of it. As for recycling: it relies on converting the product to its components through chemical, mechanical or thermal treatments, in order to transfer it into valuable materials. By using these two technologies, we can: reduce environmental pollution, that results from waste disposal, through recycling or reuse, make optimal use of natural 
resources and energy, and provide new industrial opportunities. (Sakr, A,2017).

The use of the legislative entrance: This stage must be preceded by a set of steps that facilitate

the work in order to link the legal obligation and development, besides, the improvement of the level of performance of the industry and the rationalization of resources. As the legislation constitutes an acceleration of the improvement process by encouraging companies that fail to implement, and supporting the emerging ones in the application of cleaner production. (Christopher, M. W,2005).

Steps to access cleaner production:

Maria \& Miquel's study view three steps in achieving cleaner production:

1. Industrial process: by adjusting the product design to suit the philosophy of cleaner production and improving the inputs of the industrial process using materials that does not affect humans or the surrounding environment.

2. Factory: by equipping the work environment inside the factory in accordance to environmental safety and security rules, including devices and production equipment that reduce pollution.

3.Business organization and management: By developing industrial systems in production and services, to achieve optimal use of resources and adjust the quality of industrial products.

\section{Carlos \& Auxiliadora finds that there are four} steps to implementing CP:

1. Planning and organizing: by forming a team responsible for implementing cleaner production, with the necessity of taking into consideration the representation of all members in this team, and trying to carefully listen to everyone and apply what is best. As well as creating a correlation between senior management and workers through the presence of workshops, courses and seminars to raise awareness of the importance of environmental issues for everyone and the extent of the ability of cleaner production to improve the company's environmental and economic performance. (Camila, D. W, \& Others, 2014) (Sakr, A,2017).
2. Before the evaluation: A section of the production departments is started within the company, then the circulation is made to the facility or the factory as a whole and the selection is made according to the previous studies, as is the selection of the department expected to achieve the greatest environmental improvement and the highest production efficiency when carrying out

the cleaner production, then the possibility of preparing for a process quantitative evaluation of production stages based on the information collected by the team responsible for implementing cleaner production by formulating this information in graphs and tables through which we can determine the appropriate options for each department, the expected costs and results once implemented and finally setting a timeline for implementation.

3. Evaluation: The inputs and their budget (raw materials, energy, and water) are determined, then the outputs, the causes of waste generation, and what cleaner production can provide as defined by the operational and technological requirements and the field of technical, economic and environmental studies.

4. Implementation: The implementation is partially done at the beginning, then the it is generalized, and an evaluation is made after the completion of the implementation for each stage to measure any deviations and their causes. (Carlos, H. R. M ,2013) (Sakr, A,2017).

5. The options that companies adopt to implement cleaner production:

- Changing production methods: good administrative and procedural measures are used to reduce emissions and pollutants to improve production efficiency and reduce cost.

- Changes in raw materials: the dangerous materials that go into the production process are reduced and canceled.

- Changes in product design: It means changes done to the product, whether in specifications or implementation, in order to limit the emission of waste during the use of the product or after its 
use or disposal, and these changes can lead to redesigning the product, which leads to reducing environmental impacts on the product's life cycle.

- Modify operations: changing the current processes to improve efficiency and reduce emissions. (Eric, K \& Timo, A.R ,2008).

- Better control of processes and production stages: by changing operating procedures and guidelines for the use of devices and machinery, and using methods to improve operations efficiency and reduce waste and emissions.

- Renewing products and changing technical methods: It means changing the characteristics of

the product to reach the best efficiency of the product, improving the life of the product, reducing the product's impact on the environment, and using modern technological methods.

- Technological change: it means changes that are directed towards making adjustments in places and equipment to reduce the emission of waste and pollutants. These changes may be simple that can be implemented at a low cost, or they are a total replacement of operations resulting in a large capital cost. (Johanne, F,1998).

- Reducing, reusing and recycling: It means preventing the generation of waste from its source starting from reducing the use of raw materials and energy and reusing the waste generated from them, i.e. recycling and making them useful materials through a group of treatments, and this means the repeated use of the product by changing its original use.

- The practical benefits of cleaner production:

- Increasing productivity and achieving economic cost.

- Improving production processes.

- Improve the overall shape of the facility and improve the work environment.

- Increase export opportunities. (Eric, K \& Timo, A.R ,2008).

Expected barriers to implementing CP:

- Availability of information on cleaner practices and technologies, and the lack of a suitable en- vironment for a rapid shift towards cleaner production.

- Lack of awareness among industrial establishments and insufficient awareness of government agencies.

- The absence of transparency in the industry, ambiguity and confidentiality that surrounds the business world.

- Difficulty in providing the necessary funding for the CP implementation process.

- Lack of markets for products made from recycled materials. (Marije,K, 2015) (Nicholas,K. G \& Yarhands, D. A \& Duke, P. M, 2014).

The relationship between cleaner production and environmental management systems: Integration between environmental management systems on the one hand and cleaner production on the other hand leads to ensuring sustainable

development and continuous improvement, in addition to achieving compatibility with environmental laws and legislations and improving the work environment, and this integration is achieved by addressing the fundamental causes of environmental problems, providing value added to the system and contributing to the optimal use of processes and products to increase efficiency and reduce pollution rates (Santos,S.D,2013), this integration is shown in the following form

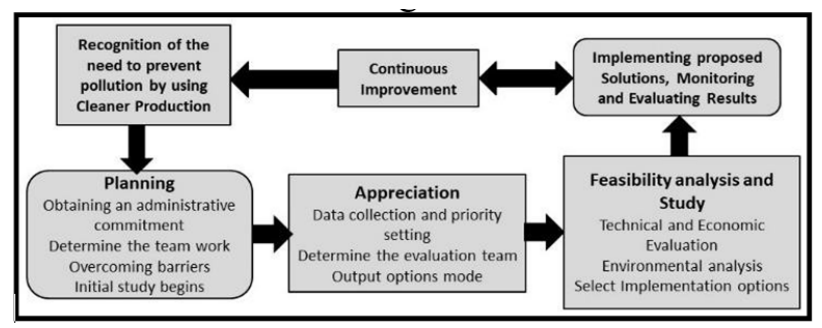

Figure (1) | illustrates Integration of Cleaner Production with Environmental Management systems. (Fore, C.T.M,2010).

\section{Carpets industry in Egypt:}

Carpets industry is one of the most recognized industries especially in the carpet machine in Egypt today, this industry has grown to become the largest and fastest-growing industry in the world especially machine made carpet manufacturing. (The Carpet and Rug Institute,2010). 
Carpets industry is the acknowledged in design, quality and innovation within the Egyptian industries, with a simple vision it become a leading worldwide exporter and by far the largest player in Egyptian market. Thus this leading Egyptian industry to perform the research practical work in quality \& environment fields to maintain its distinguished position in this industry. (Israa, M. A.k,2016).

Therefore, the researcher chose to apply the cleaner production system to the carpet industry.

Table (2) illustrates A protocol for implementing a concept cleaner production within the facility under study.

\begin{tabular}{|c|c|}
\hline $\begin{array}{l}\text { The facil- } \\
\text { ity } \\
\text { u n d e r } \\
\text { study. }\end{array}$ & $\begin{array}{l}\text { A large-sized facility that doesn't } \\
\text { comply with any of the international } \\
\text { environmental regulations or stan- } \\
\text { dards. }\end{array}$ \\
\hline $\begin{array}{l}\text { The } \\
\text { mega } \\
\text { process } \\
\text { in our } \\
\text { study }\end{array}$ & $\begin{array}{l}\text { Production order (upon customer } \\
\text { request). } \\
\text { Production plan. }\end{array}$ \\
\hline $\begin{array}{l}\text { machine } \\
\text { made } \\
\text { carpets } \\
\text { factory } \\
\text { consists } \\
\text { of } 9 \text { main } \\
\text { sub pro- } \\
\text { cesses : }\end{array}$ & $\begin{array}{l}\text { Weaving. } \\
\text { Shearing and Back coating. Finishing } \\
\text { \& Confection Final Inspection } \\
\text { Rolling and Packing. Storage in ware- } \\
\text { house. } \\
\text { Shipping and delivery to customer. } \\
\text { (Oriental Weavers-Carpet- } \\
\text { Company-Company. } \\
\text { Profile,2021.) }\end{array}$ \\
\hline Market & Eastern Europe \& USA. \\
\hline In put : & $\begin{array}{l}\text { Use of harmless, non- hazardous and } \\
\text { inferior materials . }\end{array}$ \\
\hline Process: & $\begin{array}{l}\text { Preservation of raw materials. } \\
\text { Conserving energy, water and } \\
\text { exploiting clean, } \\
\text { renewable energies such as solar } \\
\text { energy. } \\
\text { Reducing heat emissions. Reducing } \\
\text { the generation of waste through } \\
\text { replacement and renewal Processes. } \\
\text { Reducing dust by using filters }\end{array}$ \\
\hline
\end{tabular}

\begin{tabular}{|l|l|}
\hline & $\begin{array}{l}\text { Recycle and Reuse. (The Carpet } \\
\text { and Rug Institute,2010). }\end{array}$ \\
\hline $\begin{array}{l}\text { Con- } \\
\text { tinuous } \\
\text { Improve- } \\
\text { ment: }\end{array}$ & $\begin{array}{l}\text { All activities related to research, } \\
\text { studies, consultancy and develop- } \\
\text { ment. }\end{array}$ \\
\hline $\begin{array}{l}\text { Other } \\
\text { aids : }\end{array}$ & $\begin{array}{l}\text { Carpet factories have to seek to apply } \\
\text { Environmental Management System } \\
\text { (Implementing an EMS has much } \\
\text { financial, production, marketing, } \\
\text { cost saving, competitive advantage, } \\
\text { easier bank loans, improved focus and } \\
\text { employee awareness, better relations } \\
\text { with regulators, improved regulatory } \\
\text { compliance, keeping ahead of environ- } \\
\text { mental legislation } \\
\text { improved public image, customer } \\
\text { and supply chain pressure }\end{array}$ \\
\hline $\begin{array}{l}\text { Result } \\
\text { of Study }\end{array}$ & $\begin{array}{l}\text { Green Products, Improvement of } \\
\text { Environmental Performance, Max- } \\
\text { imize Profitability, Support Com- } \\
\text { petitiveness for our study carpet } \\
\text { factory. }\end{array}$ \\
\hline
\end{tabular}

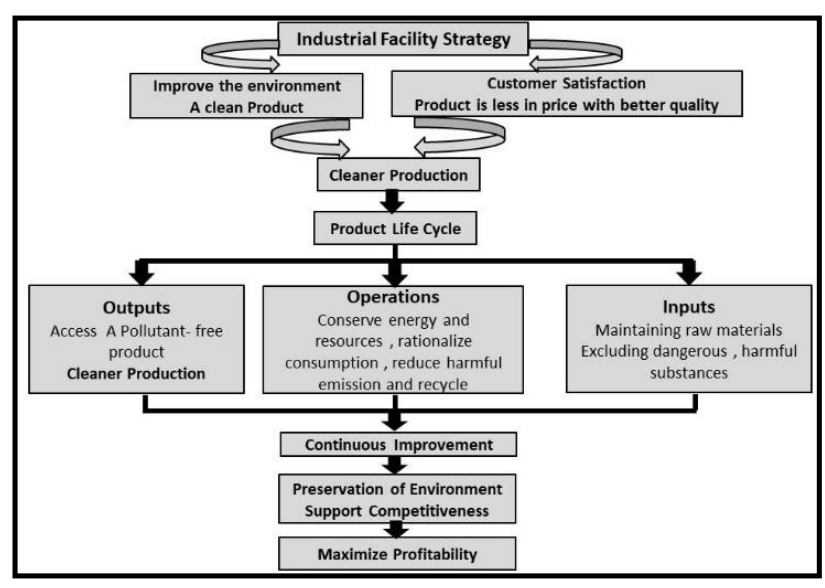

Figure (2) | illustrates proposed framework for Cleaner Production

Roadmap for Implementation the concept of Cleaner Production in our study factory:

1- Addressing a task group with top management commitment.

2- Self-assessment to definition the current status in 
factory.

3- Establish Roadmap for Implementation between all department in factory.

4- Addressing all factory production activities (inputs - process - output - packing - purchasing) cause that all economic activities involving consumption of energy raw materials and generate wastes and pollution. 5- Stakeholders show in the activity (factory needs to know what they are managing and whether management is effective and generating value or not.

6- Awareness Publication by workshops \& meetings (Environmental Performance play a key role in management and communication).

7- Implementation improvement steps \& Measuring results after implementation improvement steps.

Table (3) illustrates facility setting before implementing a concept cleaner production.

\begin{tabular}{|c|c|}
\hline Labor awareness & Low \\
\hline Safety & Partially comply \\
\hline $\begin{array}{c}\text { Environment } \\
\text { Management status }\end{array}$ & Partially comply \\
\hline Machine loading & Medium Capacity \\
\hline $\begin{array}{c}\text { Second degree } \\
\text { production }\end{array}$ & High percentage. \\
\hline
\end{tabular}

1-The stage of identifying\& measuring the causes of the problems:

Table (4) illustrates the reasons for the second degree, quantity of meters for each defect.

\begin{tabular}{|c|c|c|c|c|c|c|}
\hline $\begin{array}{c}\text { Defect } \\
\text { s } \\
\text { Type } \\
\text { Before } \\
\text { Appli } \\
\text { ng }\end{array}$ & $\begin{array}{c}\text { Stains } \\
\text { and } \\
\text { dirt }\end{array}$ & $\begin{array}{c}\text { In } \\
\text { proper } \\
\text { cross } \\
\text { cutting }\end{array}$ & $\begin{array}{c}\text { Poor } \\
\text { handl } \\
\text { ing }\end{array}$ & $\begin{array}{c}\text { In } \\
\text { proper } \\
\text { melted } \\
\text { corner } \\
\left(\begin{array}{c}\text { Wro } \\
\text { Impro } \\
\text { ve- } \\
\text { ments }\end{array}\right.\end{array}$ & $\begin{array}{c}\text { Bar- } \\
\text { cod } \\
\text { e }\end{array}$ & Tot. \\
\hline $\begin{array}{c}\text { No of } \\
\text { meters }\end{array}$ & $634 \mathrm{~m}$ & $\begin{array}{c}345 \\
\mathrm{~m}\end{array}$ & $\begin{array}{c}880 \\
\mathrm{~m}\end{array}$ & $\begin{array}{c}160 \\
\mathrm{~m}\end{array}$ & $\begin{array}{c}239 \\
\mathrm{e})\end{array}$ & $\begin{array}{c}2258 \\
\mathrm{~m}\end{array}$ \\
\hline
\end{tabular}

2-The stage of determining the most common reasons for emergence the second degree:

Table (4) illustrates the reason degree (Stains and dirt, in proper cross cutting, Poor handling, in proper melted corner (burnt surface), Wrong Barcode \& quantity of meters for each defect, for 10 looms, Since the total of 10 looms for 2 months 802000 meters.

\section{Pareto diagram shows causes of second degree}

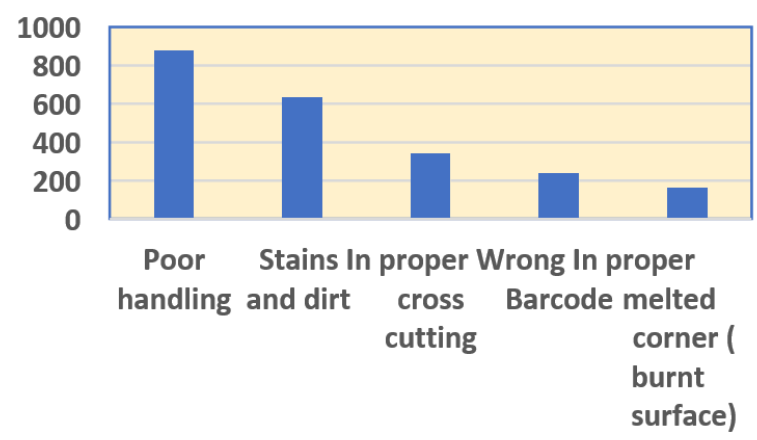

Figure (3) | illustrates pareto diagram shows causes of second degree.

\section{3- The stage of analyzing and treatment: Poor handling:}

Trolleys of the semi-finished product are waiting before moving to the next as there are jammed points in between also different processes routings are scattered on different lines/and also the flow of product until finishing processes is horizontal flow while the last stage in the main processes inside the hall which is the delivery process is vertical one which means that the last point is perpendicular on the production flow chart. This is the fact which increase the handling problem.

critical points of handling are in 3 places: Between long side over edging lines \& cross over edging line. / In QC lines. / Before final inspection \& packaging lines (as shown in the following figure): 


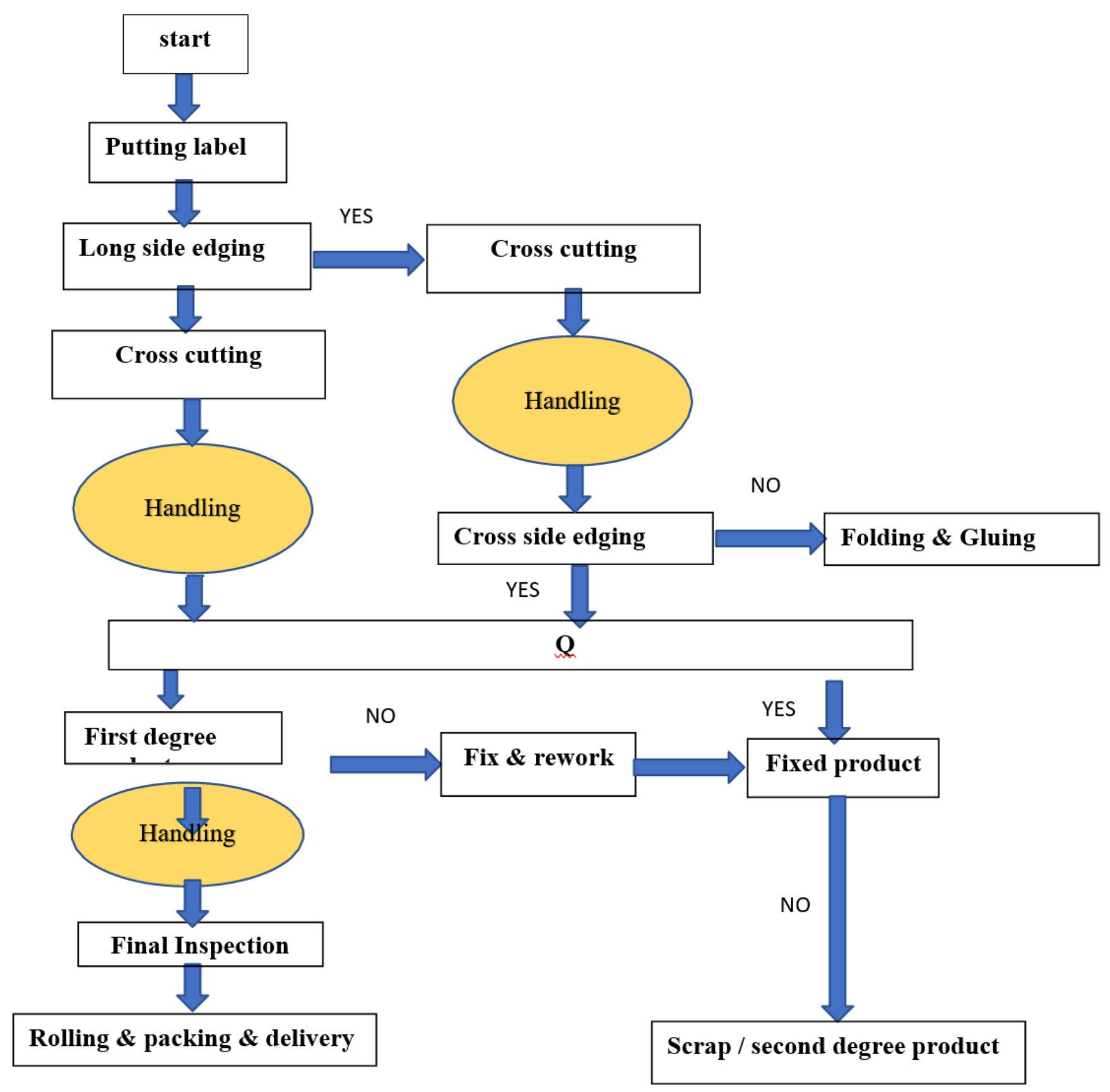

Figure (4) illustrates the poor handling problem

Poor Handling Defects in 2 places which are: Poor handling defects before cross-side finishing. \&Poor handling defects before packaging. The researcher redesigns the work flow inside finishing area (before cross-side finishing. \& before packaging) and also to make all the stages in the same direction \& the handling method in the finishing hall to avoid the previous stated jammed areas. Here we can see the flow chart with no handling processes which no delay in the whole process. (as shown in the following figure): 


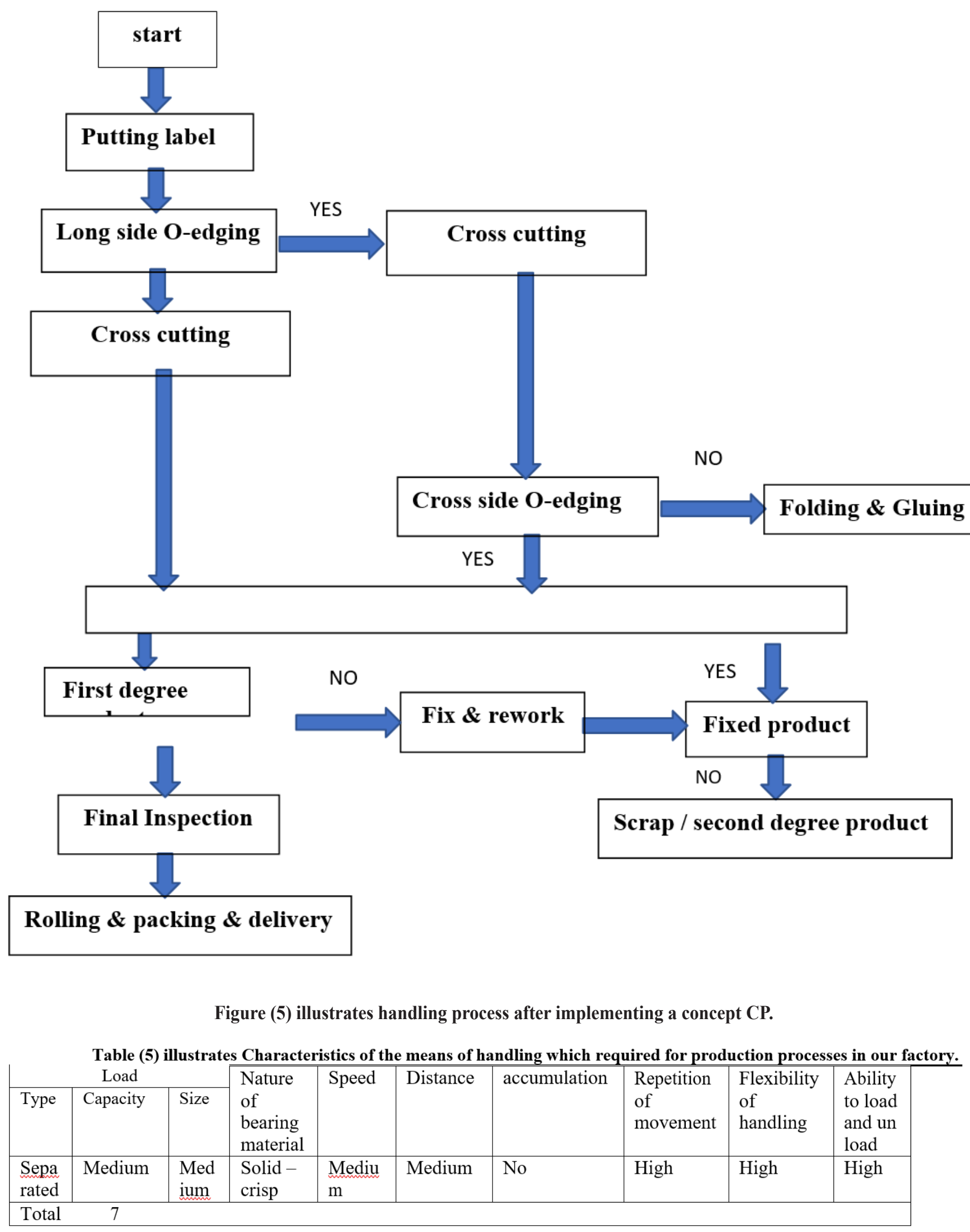

As the performance improved at a rate $17 \%$ by using the actual means of handling to achieve the production process requirements. 


\section{Strains and dirt:}

- Absence of an integrated system of cleaning Machines and corridors of raw materials and carpets and there is no statement for cleanliness status of the machine as well.

- Lack of efficiency of maintenance workers and maintenance procedures regarding lubrication operations as leaks by mistake on carpets, ground and cones.

- The defects with hood that leads to an increase of the amounts of flying dust due to the lack of an integrated system for the preventive maintenance of hoods, fans and suction stations.

- Lack of a monthly report for monitoring the quality results and the absence of a template for the annual plan to be reviewed.

- Lack of workers 'awareness. Some workers bring food and drinks inside the production halls, which leads to contamination of raw materials and machines as worker's hand is being contaminated while he $\backslash$ she wipes it with the raw materials.

- Lack of a shift system to follow up on cleanliness by quality, low efficiency of quality workers and their numbers.

\section{proposed solutions:}

- Preparing a comprehensive integrated cleaning system for the factory and reports for quality in order to review the application of comprehensive cleaning systems within the work environment as a whole.

- Preparing courses to educate maintenance workers about the importance of carrying out comprehensive maintenance of equipment and tools and about the concept of preventive maintenance and the savings it can achieve for the factory and how to carry out lubrication and lubrication operations for different parts of the machine and perform cleaning afterwards for the lubricated parts in order to reduce and eliminate the source of contamination for raw materials and products with oils.

- Preparing a full documentary cycle for the factory, including the preparation of a monthly report to monitor the quality results and the lack of a template of the annual plan to be reviewed.

- Preparing courses to educate workers about the concept of cleaner production and what it can provide if it is applied in carpet factories, and preparing a separate well-ventilated area away from the production halls for eating, with means for washing hands to reduce the waste resulting from the lack of unclean hands of workers.

\section{Laborers:}

- Conducting a periodic examination program in order to checkup health status of workers.

- Updating the instructions boards and using them to communicate the required information with employees.

- Sharing job gains with working achieved by improving the work environment.

- Educating workers about the importance of changing an action plan to make improvements within work environment inside the factory.

- Repair workers may be exposed to bodily injuries, so general preventive measures must be implemented, such as: securing machines, closing systems, and placing warning and guiding signs.

\section{Factory environment:}

- Afforestation and cultivation of the land surrounding the factory.

- Replacement and renewal of machines and equipment.

- Leveling the factory ground surface and using slopes for easy movement of raw materials and handling equipment in order to prevent accidents

\section{Users:}

Carpet maintenance guidelines (product care specifications during use):

- Using products, a little longer.

- Maintaining carpets, a little longer.

- Reducing environmental pollution.

- increasing the efficiency of used resources.

Table (6) illustrates facility setting after implementing a concept $\mathrm{CP}$.

\begin{tabular}{|c|c|}
\hline Labor awareness & Good \\
\hline Safety & Comply \\
\hline $\begin{array}{c}\text { Environment } \\
\text { Management status }\end{array}$ & Comply \\
\hline Machine loading & High Capacity \\
\hline $\begin{array}{c}\text { Second degree } \\
\text { production }\end{array}$ & Low percentage. \\
\hline
\end{tabular}

Table ( 7 ) illustrates common reasons for 2nd degree after implementing a concept $\mathrm{CP}$.

\begin{tabular}{|c|c|c|}
\hline $\begin{array}{c}\text { Defects Type } \\
\text { After Appling } \\
\text { Improvements }\end{array}$ & $\begin{array}{c}\text { Stains } \\
\text { and dirt }\end{array}$ & $\begin{array}{c}\text { Poor } \\
\text { handling }\end{array}$ \\
\hline No of meters & $314 \mathrm{~m}$ & $510 \mathrm{~m}$ \\
\hline
\end{tabular}


Table (8) illustrates form and quantities of solid, air $\&$ liquid wastes before implementing a concept CP.

\begin{tabular}{|c|c|c|}
\hline \multicolumn{3}{|c|}{ Waste } \\
\hline \multirow[t]{6}{*}{$\begin{array}{l}\text { Solid } \\
\text { wastes }\end{array}$} & $\begin{array}{l}\text { Empty oil , Spray } \\
\text { containers }\end{array}$ & $\begin{array}{l}30 \mathrm{~kg} / 2 \\
\text { months }\end{array}$ \\
\hline & $\begin{array}{l}\text { Compressors, filters, } \\
\text { generators }\end{array}$ & $\begin{array}{l}20 \mathrm{~kg} / 2 \\
\text { months }\end{array}$ \\
\hline & Plastic, Carton, Trash & $\begin{array}{l}0.5 \\
\text { tones } / 2 \\
\text { months }\end{array}$ \\
\hline & Metal & $\begin{array}{c}22 \mathrm{~kg} / 2 \\
\text { months }\end{array}$ \\
\hline & Scraps & $\begin{array}{l}0.4 \text { tones } / 2 \\
\text { months }\end{array}$ \\
\hline & Waste labels & $\begin{array}{l}16 \mathrm{~kg} / 2 \\
\text { months }\end{array}$ \\
\hline $\begin{array}{c}\text { Air } \\
\text { wastes }\end{array}$ & $\begin{array}{c}\text { Handling and } \\
\text { preparation of row } \\
\text { materials }\end{array}$ & $\begin{array}{c}100 \mathrm{~m} 3 / 2 \\
\text { months }\end{array}$ \\
\hline \multirow[t]{3}{*}{$\begin{array}{l}\text { Liquid } \\
\text { wastes }\end{array}$} & $\begin{array}{l}\text { Washing \& Cleaning } \\
\text { water. }\end{array}$ & $\begin{array}{c}150 \mathrm{~m} 3 / 2 \\
\text { months }\end{array}$ \\
\hline & Adhesive residue. & $\begin{array}{l}80 \mathrm{~m} 3 / 2 \\
\text { months }\end{array}$ \\
\hline & Sewage waste. & $\begin{array}{l}410 \mathrm{~m} 3 / 2 \\
\text { months }\end{array}$ \\
\hline
\end{tabular}

\section{Air exhaust:}

Dust caused by transporting and handling yarns and carpets is an essential source of air exhaust that may contain short natural or synthetic fibers, chemical and microbial pollutants such as, bacteria, fungi, and pesticides. Exposure to dust can cause: Chronic bronchitis, asthma, and emphysema.

The carpet industry generates some odors caused by burning oils, which are dangerous to the internal and external environment of the factory: therefore, gases produced by burning oils must be captured and recovered (installing systems such as heat recovery systems) and flue emissions should be directed to filters in order to reduce emitted odors. The textile sector requires a heavy use of energy sources to conduct heating operations, so the generated thermal energy should not exceed 50 megawatts as more than that would be a danger to the surrounding environment of the production unit. Also it is needed to work on establishing clean and renewable energy units such as solar energy as an essential source of energy generation in carpet factories.

Failure to control the temperature and humidity in the air inside the production halls leads to an increase in stress sensitivity, as high temperatures causes workers to suffer from heat exhaustion, which leads to a decrease in their productivity and their consequent need to have long periods of rest. In addition, increasing the humidity in the factory atmosphere does not help the body to get rid of the amount of heat needed to maintain its thermal equilibrium so the following procedures are needed:

- Enclosure of dust producing equipment, and use of local exhaust ventilation.

- Use of dust extraction systems and means of controlling emissions such as filters and suction cups and recycling them to remove dust, harmful objects, fumes and excess heat from the production, processing and packaging halls.

- Use of personal protective equipment (PPE) for exposed workers, such as masks and respirator in the production halls.

- Seal the doors of entrances and exits with double hinges that keep them closed constantly.

- Carry out periodic maintenance of refrigeration and ventilation systems to ensure their efficiency.

\section{Visual and noise pollutants:}

Noise increases workers' distraction, thus reducing production and increasing injuries, as working in noise causes running out of worker's energy, effort, psychological comfort, lowering his productive efficiency, as well as lack of lighting, so the following procedures are needed:

- Taking into account the necessary design considerations for dealing with noise inside the production halls and to provide halls with sound-absorbing materials.

- Providing audio units next to workers where they can receive and send their needs.

- Installing machines and on flexible rubber bases and covering their metal parts as they are sound-radiating surfaces.

- Exhaust suction fans are of main reasons for the increase of noise so shock-insulating materials can be installed such as rubber

- Using sound barriers in order the reflective and the absorptive ones. 
- Double the current distance between machines.

- Providing a separate, comfortable and clean place for meals, not the workplace, and providing it with facilities.

- Raising worker's awareness about the danger of noise and the means of available protection and their importance.

- Lining the walls and ceilings of the building with suitable insulation materials.

- Using personal protective equipment such as earplugs and helmet to reduce exposure to injuries in the production halls.

- Good lighting is an effective element in increasing production efficiency, quality and avoiding errors. One of its conditions is the clarity of all machines' parts and their accessories without any shadows on each other or on the product so problems and defects can be detected easily) light should be in a parallel row with natural lighting above the production lines).

- Redistributing of existing lighting, installing reflectors, painting ceilings and walls in light colors, and adding sources to improve general lighting.

- Clean the bulbs regularly to get higher brightness levels.

- Avoid direct or indirect glare sources for good visual function.

\section{Solid waste:}

- Cardboard: in which threads and oil bottles used in lubricating processes_are placed and paper in which it is a result of damaged paper ticket. Paper can be recycled through the stages of collection, sorting, cutting, washing,

- mixing and kneading, bleaching and processing, pressing, forming, drying and gluing, Recyclable materials should be used and purchased in production and manufacturing processes as well as environmentally friendly products in to be used in packing.

- Plastic bags and boxes (used in packing threads, oil and grease bottles): some of them can be recycled as recycling contributes in
Preserving the environment (internal and external) and reducing pollution. Recycling is a process in which an element or its components can be used to produce something else, and some are converted into fuel, diesel, oils and also used as fuel to generate electric power, and it can be used in the production of electric tracks, and industrial yarns for the manufacture of carpets and seats.

- Metal parts (a result of end-of-life spare parts such as filters, compressors, generators, machine parts and spray boxes): some of them can be reused for factories with lower quality in their production, and some are categorized according to their raw materials (aluminum, steel, iron, lead, copper) and follow the country's plan in dealing with each metal.

- Yarn waste (left on machines) and carpet scarps from cutting and preparing operations: waste fibers, bits, and scraps can be recycled as raw materials for other processes, including low grade products, nonwovens, insulation, and flooring.

- liquid exhaust (oils and greases such as transmission fluids / motor oils / brake fluids):

- Each type is stored separately, then transported and processed in special factories to be reused.

- Fluids with some adhesive exhausts: to be purified from impurities and reused after adjusting it according to the required specifications.

- Sewage, washing and cleaning water: to be purified and used in irrigating the trees surrounding the factory.

Table (9) illustrates form and quantities of solid, air \& liquid wastes after implementing a concept CP. 


\begin{tabular}{|c|c|c|}
\hline \multicolumn{3}{|c|}{ Waste } \\
\hline \multirow[t]{6}{*}{$\begin{array}{c}\text { Solid } \\
\text { wastes }\end{array}$} & $\begin{array}{c}\text { Empty oil , Spray } \\
\text { containers }\end{array}$ & $18 \mathrm{~kg} / 2$ months \\
\hline & $\begin{array}{c}\text { Compressors, filters, } \\
\text { generators }\end{array}$ & $\begin{array}{c}10 \mathrm{~kg} / 2 \\
\text { months }\end{array}$ \\
\hline & $\begin{array}{c}\text { Plastic, Carton } \\
\text {,Trash }\end{array}$ & $\begin{array}{c}0.3 \\
\text { tones } / 2 \text { months }\end{array}$ \\
\hline & Metal & $\begin{array}{c}14 \mathrm{~kg} / 2 \\
\text { months }\end{array}$ \\
\hline & Scraps & $\begin{array}{c}0.3 \text { tones } / 2 \\
\text { months }\end{array}$ \\
\hline & Waste labels & $9 \mathrm{~kg} / 2$ months \\
\hline $\begin{array}{c}\text { Air } \\
\text { wastes }\end{array}$ & $\begin{array}{c}\text { Handling and } \\
\text { preparation of row } \\
\text { materials }\end{array}$ & $\begin{array}{l}90 \mathrm{~m} 3 / 2 \\
\text { months }\end{array}$ \\
\hline \multirow[t]{3}{*}{$\begin{array}{l}\text { Liquid } \\
\text { wastes }\end{array}$} & $\begin{array}{l}\text { Washing \& Cleaning } \\
\text { water. }\end{array}$ & $\begin{array}{c}120 \mathrm{~m} 3 / 2 \\
\text { months }\end{array}$ \\
\hline & Adhesive residue. & $\begin{array}{c}60 \mathrm{~m} 3 / 2 \\
\text { months }\end{array}$ \\
\hline & Sewage waste. & $\begin{array}{c}300 \mathrm{~m} 3 / 2 \\
\text { months }\end{array}$ \\
\hline
\end{tabular}

\section{5-The stage of comparing the results}

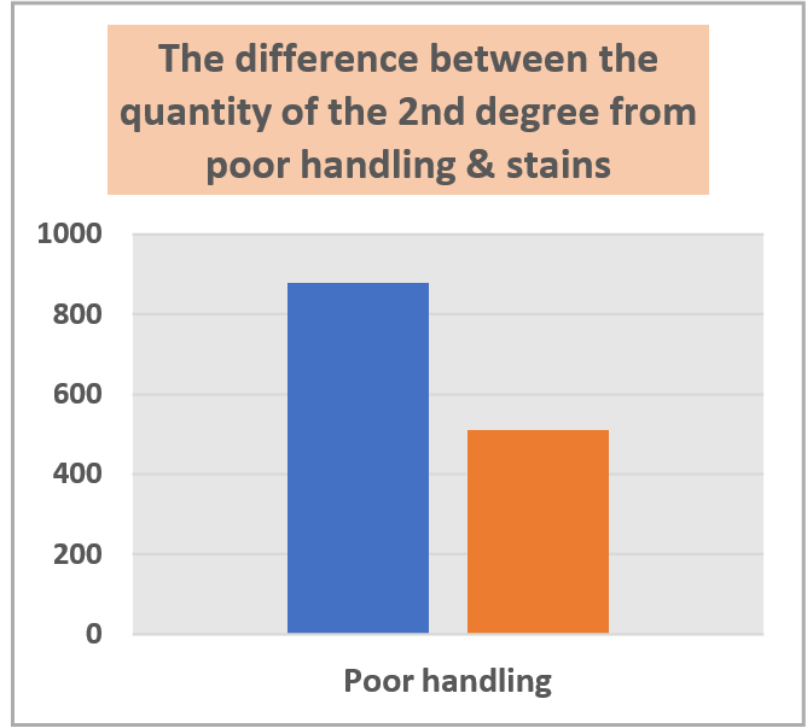

Figure (6) illustrates the difference between the quantity of the 2nd degree from poor handling \& stains before \& after implementing a concept $\mathrm{CP}$.

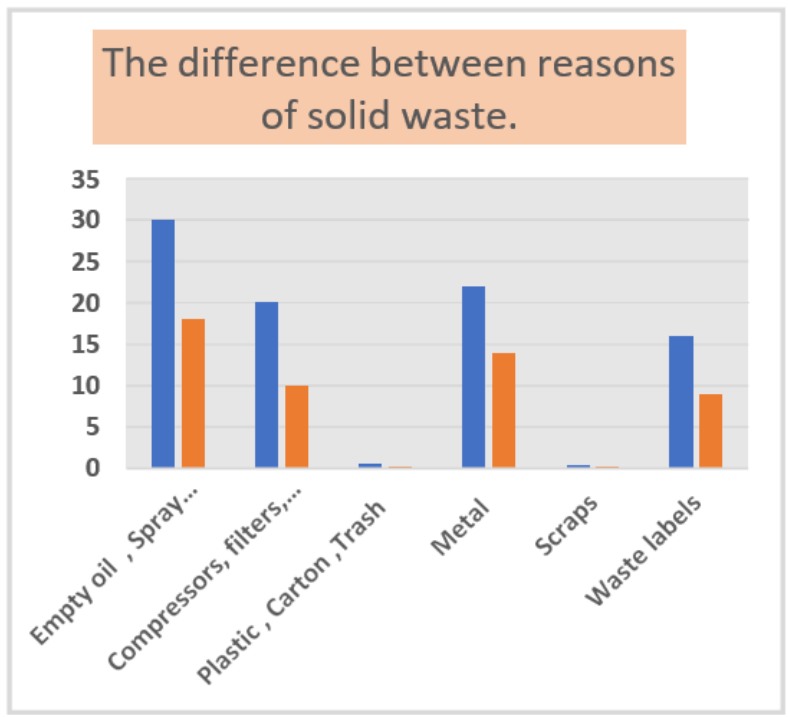

Figure (7) illustrates the difference between reasons of solid waste before \& after implementing a concept $\mathrm{CP}$

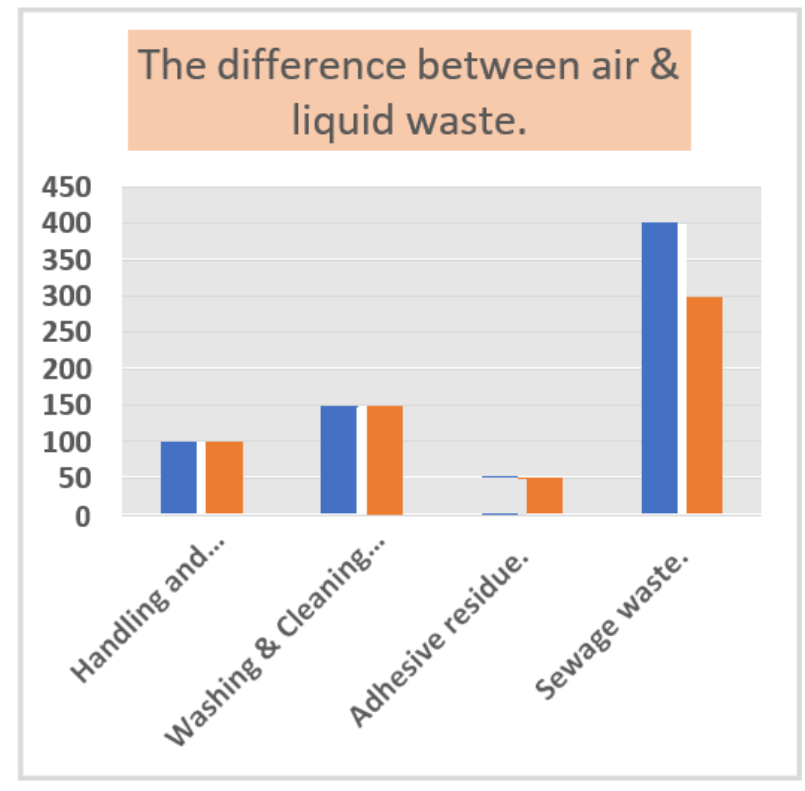

Figure (8) illustrates the difference between the quantity of air $\&$ liquid waste before \& after implementing a concept CP

5-The stage of prevention and continuous improvement:

Checklists of materials.

- Monitor consumption of materials.

- Avoid losses of raw materials.

- Optimize production planning.

- Repair leakages in pipes and equipment.

- Substitute harmful substances. 
- Reduce use of cleaning.

- Do preventive maintenance.

\section{Checklists of waste:}

- Monitor the quantities and flows of waste.

- Separate waste.

- Provide appropriate containers for waste collection.

- Reduce and avoid packaging waste.

- Reduce rejects and trade returns.

-Reuse and recycle waste.

- Safe disposal waste \& effluents. Checklists of

\section{Storage and handling of materials:}

- Inspect the quality of raw materials from suppliers.

- Establish secure storage areas.

- Appropriately stock dangerous substances.

- Avoid material losses during transfer.

- Avoid spillage and leakage.

- Improve material transfer.

- Clean and dispose of packaging material.

- Avoid losses of manufactured goods during storage and transport.

\section{Checklists of water and water waste:}

- Monitor consumption of water.

- Reduce consumption of water in production.

- Avoid spillage and optimize use of water.

- Eliminate water leakages.

- Reuse and recycle water.

- Reduce consumption of water in non- production areas.

- Conserve water used during cleaning processes.

- Avoid blockages in the waste water system.

- Reduce and avoid pollution of waste water.

- Pre-treat and safely dispose of waste water.

\section{Checklists of energy:}

- Monitor energy consumption.

- Reduce energy consumption and costs.

- Avoid energy losses.

- Adequately install electric devices.

- Adjust energy consumption to act requirements.

- Reduce of energy.

- Energy saving illumination.

- Water heating and electricity generation.

- Cooling/Freezing equipment.

- Do preventive maintenance for energy equipment.

- Consider energy efficiency in purchasing decisions.

- Deal appropriately with power cuts.

\section{Results:}

1. It was found that the proposed framework is suitable to be applied gradually to the department expected to achieve the greatest environmental improvement and the highest production efficiency, then generalize to the facility as a whole and the selection is made according to previous studies of the application process, so the frame is applicable in all textile fields and all textile factories size (small or medium or huge and bulky size).

2. The implementation of the proposed framework has helped to reduce the second degree in production resulting from wrong handling and stains and reducing solid, liquid and air waste quantities.

3. The implementation of the proposed framework has helped to reach a production that does not allow to exceed environmental safety limits in accordance to the international environmental laws and protocols.

4. Implementing the proposed framework helped achieve customer satisfaction (where customer complaints ranged from 6 complaints before implementing a concept $\mathrm{CP}$ to only one complaint after implementing a concept $\mathrm{CP}$ ) and employee satisfaction with the work environment (the rate of workers leaving factory decreased from 10 to 2 workers after implementing a concept $\mathrm{CP}$ ), help to raise awareness of workers, preserve the environment, and reduce environmental waste.

\section{Recommendations:}

1. Applying the proposed framework to the rest of the industrial companies in general and carpet companies in particular because of its ability to improve the work environment for the Egyptian industrial sector.

2. Establishing textile educational institutions of the importance of the concept of cleaner production and paying attention to the industrial work environment, and its ability to solve the problems of industry in Egypt and raise the ability to compete locally and globally.

3. The need for society as a whole to believe in the seriousness of pollution and the damage of natural and Human Resources, and give environmental management systems and concepts of cleaner production and sustainable development special attention to eliminate the phenomenon of pollution and harmful emissions.

4. Raising awareness of users and workers about the 
importance of concept of cleaner production and associated concepts such as recycling, reuse and reduce sources of waste.

\section{References:}

1. Ahmed, T \& Hamza, B, 2012, Clean Production Strategy and its Role in Environmental Protection and Achieving Sustainable Development, Journal of Economic and Financial Studies, Faculty of Economic, University of El Oued, Algeria, Issue 5.

2. Adel ,Z \& Wijdan, H. H,2012 Cleaner Production is a working method to reduce industrial pollution by applying to the National Company for Home Furniture Industry in Mosul, Al-Rafidain Development Journal, College of Administration and Economics, University of Mosul, Iraq, Issue 107, Volume 34.

3. Bing, Z \& Shuchong, Y \& Jun , B, 2013, Enterprises willingness to adopt / develop cleaner production technologies: an empirical study in Changshu, China, Journal of Cleaner Production, Vol 40.

4. Camila, D. W, \& Others, 2014, Determination of indirect water consumption and suggestions for cleaner production initiatives for the milk-producing sector in a Brazilian middle-sized dairy farming, Journal of Cleaner Production, Vol 72.

5. Carlos ,H. R. M ,2013, Implementation of a cleaner production program in a Brazilian wooden furniture factory, Journal of Cleaner Production, Vol 46.

6. Christopher, M. W,2005, Small Business Sustainability - Cleaner Production in Environmental Management Systems, MSc, Royal Road University, Canada.

7. KOSUKE ISHII,2001, Modular Design for Recyclability Implementation and Knowledge Dissemination, Journal of information systems and the environment.

8. Sakr, A,2017, Cleaner production status in the Middle East and North Africa region with special focus on Egypt, Journal of Cleaner Production, Vol 141.

9. Eric, K \& Timo, A.R ,2008, Life cycle costing: a review of published case studies, Managerial Auditing Journal, Vol 23.

10. Johanne,F,1998, Cleaner Production as a mean for effective environmental management, Journal of Cleaner Production, Vol 6.

11. Marije,K, 2015, Total Quality Management - Advanced and Intelligent Approaches, detailed program TQM Conference, in United Association of Serbia for quality.

12. Nicholas,K. G \& Yarhands, D. A \& Duke, P. M, 2014, Managerial role in ensuring successful total quality management program me in Ghanaian printing firms, The TQM Journal, Vol 26.

13. Santos,S.D,2013, Environmental Economic Regulations and innovative capability: The clean develop- ment mechanism, Ph.D. Egade Business School, Mexico .

14. Fore,C.T.M,2010, Cleaner Production for environmental conscious manufacturing in the foundry industry , Journal of Engineering, Design and Technology , Vol 8 .

15. The Carpet and Rug Institute (CRI) - Carpet and Rug Construction, 2010, http: //www.carpet-rug.org Available at: http://www.carpet-rug.org/Carpet-for- Business/ Specifying-the-Right-Carpet/Carpet-and- Rug-Construction.aspx .(Accessed:1 January 2020)

16. Israa, M. A.k,2016, Effect of Business Processes Reengineering (BPR) on Enhancing the Performance in Textile Industries, Master Thesis, Spinning, Weaving \& Knitting Department, Faculty of Applied Arts, Helwan University.

17. Oriental Weavers-Carpet-Company-Company. Profile,2021. http: //I r. oriental weavers. com/ en/company-profile-Avilable.at: http://ir.orientalweavers. com/en/ company-profile. 